УДК 616.83/.85+616.1+616.4

DOI: $10.33184 / \mathrm{NShvb}-2021-11-22.12$

Стычинский Дмитрий Станиславович магистрант факультета психологии Башкирского государственного университета

Научный руководитель - Щербаков С. В.

\title{
ОСОБЕННОСТИ КРИТИЧЕСКОГО МЫШЛЕНИЯ У ЛИЦ, СТРАДАЮЩИХ СЕРДЕЧНО-СОСУДИСТЫМИ ЗАБОЛЕВАНИЯМИ
}

Аннотация. В статье рассматриваются отличительные особенности критического мышления у лии с сердечнососудистыми заболеваниями.

Ключевые слова: критическое мышление, сердечно-сосудистые заболевания.

Мышление является высшей ступенью познания; его можно определить в качестве процесса, отражающего в человеческой психике разнообразные связи между явлениями окружающей действительности и их объектами. В свою очередь, критика (с греческого языка переводится как обсуждение, разбор того или иного предмета, поступка, события) представляет собою определенный род социальных отношений, которые предполагают, что о выбранном объекте выносятся какие-либо порицательные суждения.

Перейдем к понятию критического мышления. Критическое мышление относится к числу интеллектуальной человеческой деятельности, обладающей достаточно высоким уровнем восприятия и понимания, а также отличающейся объективным подходом ко всей поступающей и «обрабатываемой» субъектом восприятия информации. Оно позволят определять слабые и сильные места, устанавливать правдивость фактов, выстраивать логические цепочки. Если рассматривать критическое мышление с психологических позиций, критическое мышление - это разумное рефлексивное мышление, сфокусированное на решении того, во что верить и что делать (Д. Браус, Д. Вуд) [1]; использование таких когнитивных навыков и стратегий, которые 
увеличивают вероятность получения желательного результата, отличается взвешенностью, логичностью и целенаправленностью (Д. Халперн) [7].

Критическое мышление не следует отождествлять с негативностью или же самой критикой; критическое мышление лишь предполагает разумный взгляд субъекта на рассматриваемую проблему прежде, чем вынести определенное суждение. Таким образом, главный смысл критического мышления - «ничего не принимать на веру», ставить все под сомнение. Изучение феномена критичности мышления в наиболее широком смысле дает возможность изыскателям рассматривать ее в качестве одного из компонентов, составляющих самосознание, которое обеспечивает человеку как контроль отдельных действий, так и всего поведения.

От наличия у человека критического мышления зависит его успешность в самых разнообразных областях деятельности - образовании, науке, управлении и т.д., и в особенности в повседневной жизни. Весьма важен этот навык приобретает и при оценке жизненных ситуаций в случае болезни.

Согласно данным разнообразных статистических исследований, заболевания сердечнососудистой системы входят в число наиболее распространенных по уровню болезненности и смертности, что подчеркивает актуальность проблемы. Среди сердечнососудистых заболеваний наибольшим распространением пользуются ишемическая болезнь сердца, артериальная гипертензия, атеросклероз, фибрилляция предсердий и пр. патологии кровеносной системы. Но сердечнососудистые заболевания влияют не только на физическое здоровье человека; весьма часто они являются причиной, которая обуславливает появление и развитие у пациента каких-либо когнитивных нарушений. Подобные нарушения находят проявление в расстройствах памяти и речи, влияют на временную ориентацию и ориентацию в пространстве, эмоциональное состояние человека, а также могут нести вред способности человека критически оценивать ситуацию и замедлять процессы мышления в целом.

Итак, сердечнососудистые заболевания относятся к числу заболеваний, несущих чрезвычайно высокий риск для жизни у их обладателей: инфаркт, «коронарное событие» и т.д. Отрицательно влияет и восприятие человека факта заболевания, ожидание возможной госпитализации и страхи перед лечением с применением хирургического вмешательства, которые несут в своем комплексе негативное воздействие на психологическое благополучие человека, способствуют появлению 
депрессивных состояний и чувства тревоги. Распространено мнение, что когнитивные нарушения провоцируют заболевания сердечнососудистой системы, и в связи с этим своевременность проведения коррекционной работы чрезвычайно возрастает, поскольку именно она способна улучшить исход заболевания: «все болезни человека происходят от нервов». Таким образом, следует отметить двусторонний, «замкнутый» характер связи сердечнососудистых заболеваний и когнитивных нарушений: первые способствуют когнитивным нарушениям, вторые провоцируют подобные заболевания.

Так, к числу наиболее распространенных у пациентов с ССЗ относят состояния повышенной тревоги и депрессивные расстройства, которые влияют на поступки, чувства, эмоции и мыслительные процессы., в т.ч. на социальную адаптацию. Многочисленные исследования подчеркивают, что особенное проявление тревожности отмечается у лиц, страдающих ишемической болезнью сердца.

Если оценивать результаты анализа научно-методической литературы с точки зрения формальной логики, все выглядит полнее логичным. Человек, ощущающий себя в состоянии опасности, склонен оценивать окружающую его действительность с позиций негативизма и точки зрения особого «неприятия». Повышенная чувствительность к банальным событиям (гипертрофированная реакция на бытовые ситуации), возникновение суицидальных мыслей, депрессия, замедление мыслительных процессов и запоминания, ангедония, ухудшение концентрации внимания, - вот, что нарушает способность человека критически интерпретировать действительность, т.е. ту способность, без которой ему не обойтись в 21 веке ввиду обилия информации.

«Страдает» и прогнозирующая функция критического мышления, предполагающая предвосхищение результатов - больной заранее настроен на неблагоприятный исход, и в связи с этим падает самооценка личности, во многом обуславливающая творческую деятельность. Человек может считать себя «проигравшим». Он более подавлен, раздражителен, склонен к самообвинениям и апатии, а также игнорирует позитивные стороны. При этом зачастую больные СС3 зачастую не осознают наличие у себя депрессии и тревожности, объясняя свое психологическое состояние физическими факторами.

Вместе с тем, характеризуя больных сердечнососудистыми заболеваниями, нельзя сказать, что все они склонны к тревоге или депрессии. При составлении программы психологической помощи лицам 
с СС3 следует брать в учет и темперамент больного: к примеру, более долгой и кропотливо работы потребуется уделить меланхоликам, нежели сангвиникам.

Если проанализировать существующую научную литературу по проблеме исследования, можно сделать следующие выводы. В литературе накоплено значительное количество материалов по вопросу критического мышления и заболеваниям и сердечнососудистой системы, но проблема их взаимосвязи остается открытой: в настоящее время специальные работы, посвященные особенностям критического мышления у пациентов с нарушениями сердечнососудистой системы, отсутствуют.

\section{Список использованных источников}

1. Браус Дж., Вуд Д. Инвайронментальное образование в школах: Руководство: как разработать эффективную программу / Дж. Браус, Д. Вуд; пер. с англ. СПб., 1994. - 276 с.

2. Едифанова А.С. Особенности психологической коррекции больных с сердечно-сосудистыми заболеваниями // Состояние и перспективы развития инновационных технологий в России и за рубежом. Сборник материалов I Международной научно-практической конференции. Чувашский государственный университет им. И.Н. Ульянова. 2016. С. 88-93.

3. Изнак А.Ф. Современные представления о нейрофизиологических основах депрессивных расстройств // Депрессия и коморбидные расстройства (под ред. А.Б. Смулевича). 1997. М.: НЦПЗ PAMH. C. 166-179.

4. Киселева М.Г. Психологические факторы и течение сердечнососудистых заболеваний // Национальный психологический журнал. 2012. №1 (7) С.124-130.

5. Нургалиева Н.Ф., Напалков Д.А. Депрессия и сердечнососудистые заболевания // Вестник РАМН. 2014. № 9-10.

6. Смулевич А.Б. Депрессия как общемедицинская проблема; вопросы клиники и терапии // Психиатрия и психофар-макоггерапия. 2006. T. 8. № 3. С. 4-10.

7. Халперн Д. Психология критического мышления. - СПб., 2000. $-512 c$.

( С Стычинский Д. С. 2021 